\title{
THE HISTORICAL FOUNDATIONS. HISTORICAL ARCHITECTURAL TREATY HOW INFORMATION SOURCE OF THE ARCHITECTONIC HERITAGE
}

\author{
Fernando DA CASA, Ernesto ECHEVERRIA, and Flavio CELIS. * \\ *School of Architecture, Research Group: “Intervención en el Patrimonio y Arquitectura \\ Sostenible". University of Alcalá de Henares, \\ C/ Santa Ursula 8. Alcalá de Henares. Madrid, Spain \\ fernando.casa@uah.es
}

\begin{abstract}
Keywords: Architectural Heritage Conservation, Historical Architectural treaty, historical foundation.
\end{abstract}

\begin{abstract}
In order to address architectural heritage conservation, we must be familiar with the medium with which we will be working, its function and response to incidents or external actions (natural or anthropogenic) and how the buildings were conceived and constructed in order to understand how they will be affected by the intervention process to which they will be subjected and adopt the adequate measures so these processes will not harm the buildings. An important element is the foundation. This is a fundamental, yet often forgotten, element. It is important to know the history of the foundations, how and why they were constructed and for this, it is essential to study architectural treatises as the origin of their design. It is surprising to read classical architecture treatises and observe that they do not refer to calculations of dimensions, but to constructive solutions that today may seem clever because they are obvious, but in reality, they do not address the thoughts of the designer or builder. The historic architectural treatises on construction that significantly influenced Spanish construction, which we studied and will present in this article, include Vitruvius and Palladio as well as the developments in the eighteenth and nineteenth centuries, and even into the first half of the twentieth century: (Vitruvius ( $1^{\text {st }}$ century BC), Palladio (1524), Alberti (1582), Cristóbal de Rojas (1598), Fray Laurencio San Nicolás (1639), Brizguz y Bru (1738), Rieger (1763), Fornes y Gurrea (1841), Espinosa (1859), Marcos y Bausá (1879), Ger y Lobez (1898) and Barberot (1927).
\end{abstract}

\section{INTRODUCTION}

Interventions focused on the conservation of historic buildings are a relatively recent reality in the social context, when there is concern to conserve the "historic memory" of the population, including buildings and monuments as a fundamental part of this memory. Knowing how the foundation behaves is fundamental because it is the starting point of the building. Historic foundations are even more important because they do not respond to the current types of concrete foundations built today [4]. In the past, Alberti [2] warned: "So much of what happens below ground is unknown, that to entrust it with the responsibility of bearing a structural and financial burden can never be done without risk. And so, especially in the foundations, where more than anywhere else in the building the thought and attention of a careful and circumspect builder are required, nothing must be overlooked. A mistake elsewhere will cause less damage, and be less difficult to rectify and more easily borne, but in the foundations a mistake is inexcusable." If we are working on an existing foundation without proper knowledge of this element, the problems can multiply. Many interventions on this element have been completed without knowledge of the construction system on which it was based. As Jacques Heimman said, "the most impressive thing about historic buildings is that some of them still exist," adding, "although they have been manipulated as they have."

\section{HISTORIC FOUNDATIONS AND THEIR UNIQUENESS}

The conditions in which, historically, a foundation was initially planned could vary greatly. Sometimes, these elements needed to be built on a variety of terrains, some even inadequate to support the loads these elements transmitted. Their location was sometimes determined by aspects that had nothing to do with their constructive condition and there are references to "unhealthy" locations due to the supervision and defense of trade roads (as in the case of Calatrava la vieja). All of this implies that the terrain conditions could be inadequate for building [4]. Another factor was the material used to build these foundations. It was not considered an important factor and materials were usually low 
quality and heterogeneous, and degeneration processes were not controlled. In addition, it was impossible to carry out regular maintenance operations.

The lack of geotechnical knowledge was notorious, because geotechnics is a modern science. It was a process of trial and error. When we are going to work on a historic foundation, we may encounter conditions in which to do so. This will depend on the foundation itself, as well as other aspects, including the building's characteristics and historic nature [3,5]. We must know how to look, as Victor Hugo said, "How sad to think that nature speaks and mankind does not listen," and using a medical metaphor, therapy should be based on a good diagnosis. This diagnosis is not found, but looked for. In this case, it is important to look for the sources. For this, it is important to know the history of the foundations, how and why they were built in a certain manner. It is important to study architectural treatises as the origin of design. In addition, it is surprising to see that these historic architectural treatises (from Vitruvius to Benito Bails, including Alberti) do not make reference to dimensions via calculations, but present guidelines for construction solutions that we might consider surprising today.

\section{HISTORIC SOURCES: ARCHITECTURE AND CONSTRUCTION TREATISES}

Historic architecture - construction treatises that have significantly influenced construction in Spain include the following:

$\begin{array}{ll}1^{\text {st }} \text { C. BC } & \text { The Ten Books of Architecture } \\ 1524 & \text { The Four Books on Architecture } \\ 1582 & \text { The Art of Building in Ten Books } \\ 1598 & \text { Teoría y práctica de Fortificación } \\ 1639 & \text { Arte y Uso de Arquitectura } \\ 1738 & \text { Escuela de Arquitectura Civil } \\ 1763 & \text { Elementos de Toda la Arquitectura } \\ 1841 & \text { Práctica del Arte de Edificar } \\ 1859 & \text { Construcciones de Albañilería } \\ 1879 & \text { Manual Del Albañil } \\ 1898 & \text { Construcción Civil } \\ 1927 & \text { Tratado práctico de edificación }\end{array}$

Marcus Vitruvius Pollio
Andrea Palladio [6]
Leon Battista Alberti [2]
Cristóbal de Rojas [7]
Fray Laurencio San Nicolás [8]
A. Genaro Brizguz y Bru [9]
Christian Rieger [10]
Manuel Fornes y Gurrea [11]
P. Celestino Espinosa [12]
Ricardo Marcos y Bausá [13]
Florencio Ger y Lobez [14]
Ëtienne Barberot [15]

Concerning the analysis of the documents mentioned above in the parts where they develop aspects related to building foundations, we must indicate that these texts include precise instructions on how to estimate the size of foundations and build them. In the $1^{\text {st }}$ century, Vitruvius indicated [1]:

- "The foundations of these works should be dug out of the solid ground, if it can be found, and carried down into solid ground as far as the magnitude of the work shall seem to require, and the whole substructure should be as solid as it can possibly be laid.

- "Houses which are set level with the ground will no doubt last to a great age, if their foundations are laid in the manner which we have explained in the earlier book, with regard to city walls and theatres. But if underground rooms and vaults are intended, their foundations ought to be thicker than the walls which are to be constructed in the upper part of the house, and the walls, piers, and columns of the latter should be set perpendicularly over the middle of the foundation walls below, so that they may have a solid bearing; for if the load of the walls or columns rests on the middle of spans they can have no permanent durability."

- "Above ground, let walls be laid under the columns, thicker by one half than the columns are to be, so that the lower may be stronger than the higher. Hence they are called "stereobates"; for they take the load. And the projections of the bases should not extend beyond this solid foundation.

During the Renaissance, Leon Battista Alberti [2] considered Vitruvius' specifications and developed them further:

- "In setting out the foundations, it should be noted that the base of the wall and the plinth (which are also considered part of the foundations) must be somewhat wider than the proposed wall - for the very same reason for which people who walk through the snow in the Tuscan Alps strap to their feet rackets strung with cord, since the enlarged footprint will prevent them from sinking so much."

- "Finally, the whole base of the trench must be made absolutely level, without sloping in any direction, so that the imposed load will be distributed evenly; for it is in the very nature of weights to veer toward the lowers point."

- "With rows of columns, then, there is no need to fill an extended trench with one continuous structure; it is better first to strengthen the seats or beds of the columns themselves and then to link each of these with an inverted arch, with its 
back facing downward, so that the level of the area becomes its chord. The ready support given by the arches will help to prevent the ground from giving way under the different loads that converge on a single point from all sides."

In addition, we can find specific references to the importance of being aware of the nature of the subfloor in Brizguz $y$ Bru, in 1738, [9 ]in the second chapter of his book called "De los fundamentos y de algunas condiciones que se deben observar para firmeza y seguridad de los edificios" (On foundations and some conditions to be observed for the firmness and safety of buildings). He warned that "the most important knowledge an architect can have concerns the nature of the terrain, the depths of the land." This sheds light on the importance that knowledge of the subfloor and the types of terrain had at that time. Concerning foundations, Vitruvius emphasised the importance of correct construction in order to avoid subsequent problems: "There is nothing to which an architect should devote more thought than to the structure of the foundations." [1]. Palladio, often citing Vitruvius and Alberti, indicated: "The foundations or base of a building is the part of its walls that is under ground and sustains the building's load. Of the errors committed in the art of building, the most damaging are the ones made in the foundations, because they cause the ruin of the entire building and cannot be repaired without much difficulty and expense." [6]. It is interesting to note that Alberti [2] did not consider the foundations part of the building: "The foundations, unless I am mistaken, are not part of the structure itself; rather they constitute a base on which the structure proper is to be raised and built." He continues: "A foundation - that is to say, "a going to the bottom" - and a trench will be necessary wherever a pit must be dug to reach solid ground [...] of stone, for example." He confers great importance, however, on a structure's foundations: "So much of what happens below ground is unknown, that to entrust it with the responsibility of bearing a structural and financial burden can never be done without risk. And so, especially in the foundations, where more than anywhere else in the building the thought and attention of a careful and circumspect builder are required, nothing must be overlooked. A mistake elsewhere will cause less damage, and be less difficult to rectify and more easily borne, but in the foundations a mistake is inexcusable." To conclude with this reference, in this quote, we may identify the possible reason for the absence of the details of the foundations in architectural projects. Where the building edge meets the ground, we usually find a line and then simply the white of the paper, or at best, "a trench filled with stone."

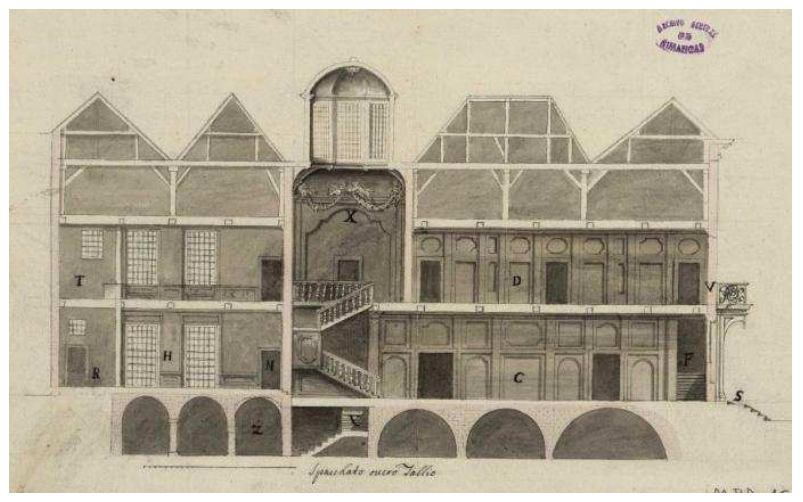

Figure 1. Plan of the King's house in The Hague. The Simancas Archive.

It would now be interesting to recall Siegfried Giedion's statement concerning the split between science and technology on one hand, and art on the other, in reference to construction and architecture. This aspect is also reflected in these documents because we can see how the aesthetic and formal aspects are treated independently, with respect to the relationship to the construction of these aspects. For the casual reader, it may seem that the treatises only deal with one aspect or the other, depending on the volume in question. We should indicate that in 1763, Rieger [4], in chapter III, "List of the main parts of any building and its constitution in detail", defines the foundation of a building and differentiates it, for the first time in such treatises, from the two parts that comprise it: "the part under the earth, or the base of all elements. The foundation is the first and deepest part of the building, on which everything else is based, and is divided into foundation and base. The foundation is the trench itself in which the deepest part of the wall is inserted. The base is the structure or construction that sustains the entire building." It was the first time that the structural nature was specifically addressed. A foundation is a trench. Until then, only the term foundation was addressed. Espinosa (1859) [12] describes only two types of terrain: firm terrain comprised of "naturally compact earth including clay, stones and rocks," or terrains that are loose and compactable, including "muddy terrain, or those with loose sand if not contained on all sides, plains that are not consolidated by the action of time, etc." For this author, and those before him, it is possible to build on any of the types of grounds or terrains mentioned above, although it is necessary to correctly calculate the size of the foundations and correctly use various auxiliary systems to prevent future problems. Marcos y 
Bausá (1879) [13], unlike the others who first examine the ground and then begin excavating, proposes the excavation first and then the subsequent examining of the ground to verify its suitability, in other words, "Once you have found the terrain that seems firm, you must probe it to see if the nature of the ground changes as depth increases, using an iron probe or rod with one end toothed and a crossbar on the other, also in iron; the rod is inserted into the ground vertically, careful as to not bend it, having rubbed the teeth* with fat, and once it has been introduced completely, it should be rotated like a drill, then removed carefully so that the soil from the deepest parts remains stuck to the fat on the toothed end of the rod." It is not enough, however, to know if the lower layers of the ground where the foundations will be located are consistent and resistant. It is also necessary to verify the existence or lack of shafts that could sink the foundations. For this, he again proposes two rebound tests, both already explained: "To verify the presence of underground shafts, you must hit the ground firmly with a wooden plank or "pisón"; you must then judge by the hollowness of the resulting sound. You may also use a bucket full of water placed on the ground with a small piece of paper on the surface of the water, placed so that the top of the paper does not get wet, then hit the ground firmly next to the bucket and if the water does not move and the paper remains dry, then the ground is firm." In this last case, the traditional movement of the water was substituted by the wetting of the paper as an indicator of the firmness of the ground. Ger y Lobez (1898) [14] in his chapter "On foundations and grounds for building", when he first addresses foundations, he divides them into two large groups depending on the existence or lack of water:

\footnotetext{
- "Ordinary, if they are established in dry land where it is easy to excavate until sufficiently solid ground is reached, without the existence of water."

"Hydraulic when these must be laid in wet ground or over springs or in terrain that is covered by water."
}

Of the authors mentioned in this article, Ger y Lobez is the one that can be considered the first to base his calculations not only on experience, but also on certain scientific premises. Despite this fact, it is quite easy to assume that these calculations are not valid for all types of grounds or terrain, or for all the different construction methods used to build foundations. In the first method and despite its apparent solidity, the size is calculated based on the resistance of the construction and not of the ground, so that the future structure could suffer unbearable loads coming from the building. In the second method, the size calculated would only be valid for the foundation building method for which it was established, packing or tamping compactable ground. But it should be taken into account that these terrains have average resistances, and this method would not work if they were of low quality or if the terrain were marshy. Barberot (1927) [15]was the first author to openly show a clear and precise example of how to calculate the size of foundations, valid for all types of ground, because it relates the terrain's resistance to the approximate load that the structure will transmit to the ground. Because of this, the terrain's resistance must be known and he included a table with approximate resistances in his treatise.

\section{REFERENCE TO SPECIAL FOUNDATIONS}

It is interesting to find references to the application of "specific techniques" when working on unsuitable grounds or soils. For example, Vitruvius mentions specific techniques for working on unstable or marshy ground: "If, however, solid ground cannot be found, but the place proves to be nothing but a heap of loose earth to the very bottom, or a marsh, then it must be dug up and cleared out and set with piles made of charred alder or olive wood or oak, and these must be driven down by machinery, very closely together like bridge-piles, and the intervals between them filled in with charred coal, and finally the foundations are to be laid on them in the most solid form of construction." [1]

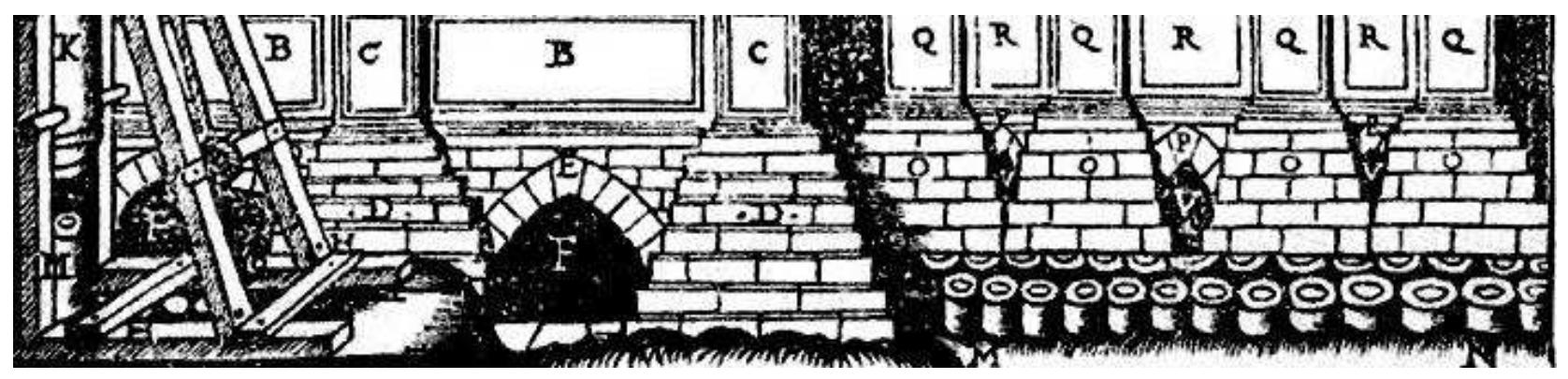

Figure 2: Illustration from the Ten Books of Architecture. Vitruvius (1st Century BC) 
Another similar reference possibly influenced by the previous text, concerns Palladio [6] and his chapters on foundations (chapter VII "On the types of ground where foundations must be laid" and chapter VIII "On foundations"). Palladio explains how to build foundations on marshy ground, explaining: "[...]dig until a firm and solid base is found or, if this proves difficult, excavate some of the sand and gravel and put in piling until the points of the oak piles reach good and solid ground." These techniques also apply to sandy or gravelly ground and around rivers or river beds. In this last case, he explains the procedure to be followed when the solid ground is located deep within the earth: "[...] then sink piles, which should each be an eighth of the height of the walls long and a twelfth of their own length thick. The piles should be driven so close to one another that no more could be inserted." Other texts mention similar procedures to the ones described above, although it is Rieger's text (Elements of Architecture, 1763) [10] that makes references to new techniques, for example, "for building on soft sand, lay the beams horizontally on the ground," as shown in the figure at the beginning of the previous section. There are various warnings concerning foundations laid in grounds of diverse consistency and recommendations include acting with the same caution as when building on poor quality terrain, as a first reference to the problem of differential settlement. He also makes references to foundations built with piles and inverted arches, as recommended by Alberti and other authors, because the inverted arch was considered the better method compared to the ordinary arch, where the inverted arch has solid and resistant wall underneath it and the ordinary arch has nothing but air.

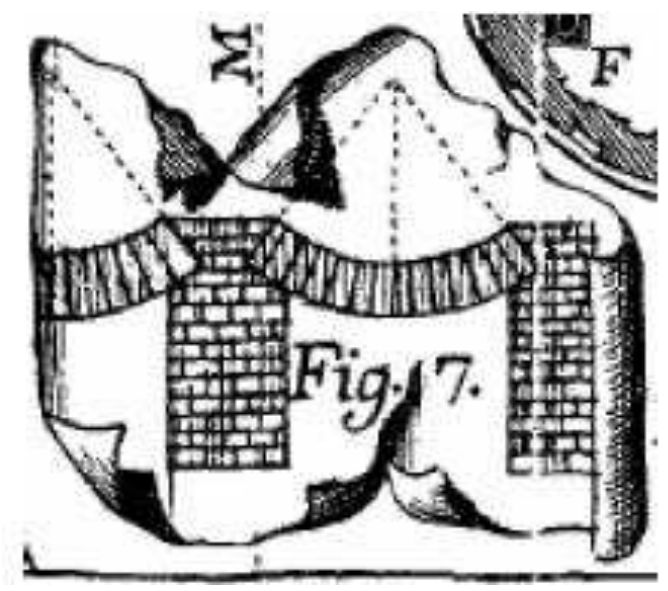

Figure 3: Illustration XX. Fig 7. Christian Rieger (1763)

References to other techniques, like pile driving, are more developed in Marcos y Bausa's text, [13] in which the author indicates the driving of wooden piles "a plomo" (straight down, vertically), where the pile heads should be protected with an iron cap to prevent splintering, then placing wooden beams on top to create a strong base, along with the correct tamping of the interstitial materials in order to "build the foundations on this structure."

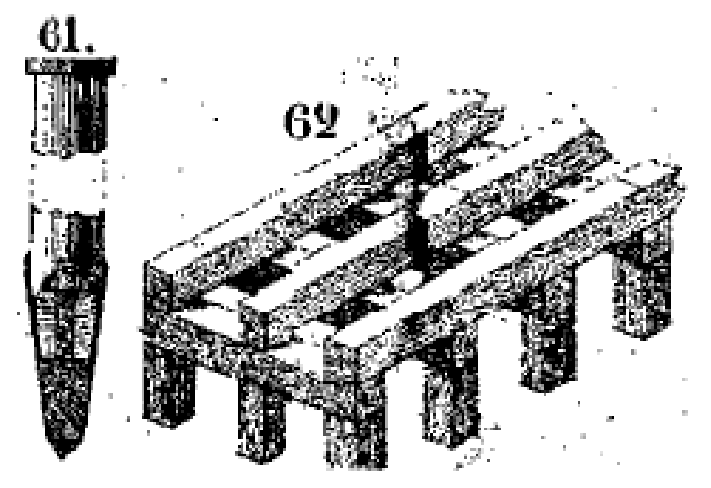

Figure 4: Illustration by Marcos y Bausá (1879) 
This reference makes it clear that the new element is not considered part of the foundation itself, but more like the "treatment of the terrain" necessary in order to begin building the foundations. In Celestino Espinosa's treatise [12], we find the first references to the use of concrete in piles, but in a unique way, because once the wooden pile is inserted, "as it is being driven into the ground, it is turned a few times, then a bar is inserted in the small hole that opens up around the pile; an iron collar ensures that the head will not splinter. This way, the terrain wall is flattened and can be more easily removed. The concrete is poured into this hole." Already in the twentieth century, Barberot develops a more complete method in his treatise concerning the techniques for pile driving, placing particular emphasis on the construction of the wooden elements, also indicating that "reinforced concrete piles are made that have very good results," although the instructions he gives do not include specifications of the material used [15].

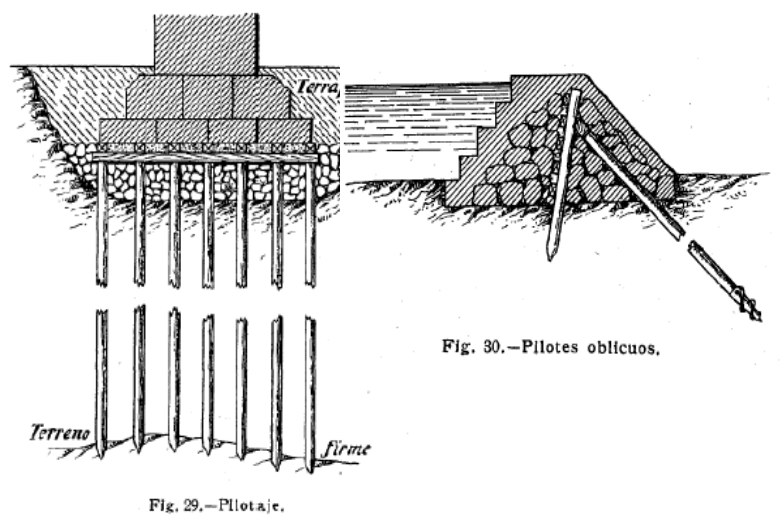

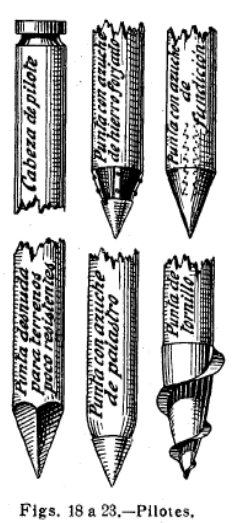

Figs. 18 a $23,-$ Pilotes.

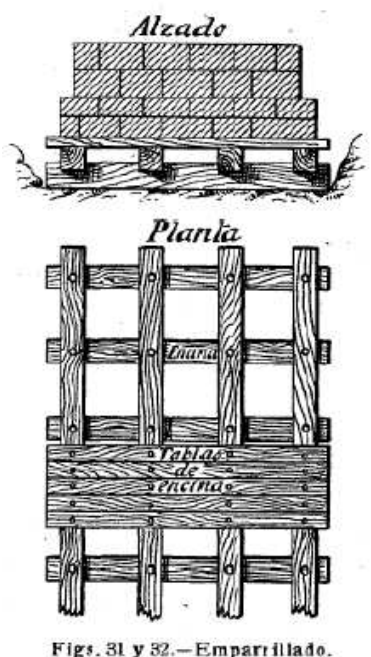

Figs. 31 y 32.-Emparitlado.

Figure 5: Illustration from the Practical Treatise on Building (Ëtienne Barberot 1927)

Last, it should be indicated that the solutions for muddy ground are the same ones given in the first treatises concerning the building of strong bases with wooden structures.

\section{CONCLUSION}

It is interesting when, by chance, one searches for or reads documentation related to architecture treatises or the origins of constructive processes. The reader is often surprised to see issues that relate perfectly to modern times. These aspects of technique are the "ancestors" of our modern techniques, and the reasons for their use are perfectly reasoned and justified with "modern" assumptions. Throughout history, man has often asked himself "why?" and this can be considered the beginning of the evolution of technology. Once the "traditional" form was developed and applied, as time passed without the application of innovations in technology, those who used the traditional techniques "as they have always done", did so because they did not know or had forgotten to ask themselves "why?" And this is basically one of the great problems of modern construction. Many technicians do not know the origins of the systems they apply; in fact these origins are not part of our education. That is why it is important to return to our roots, learn from our ancestors, recall and remember our history. The use of historic treatises as a source of knowledge is the first step.

\section{REFERENCES}

[1] Vitrubio, Los diez libros de Arquitectura, Libro III, cap III. Traducido por Carmen Andréu. Ed. Unión Explosivos Riotinto. Madrid.1972

[2] León Bautista Alberti, Los diez libros de la Arquitectura, Libro III, cap II, traducido por Francisco Lozano, Alonso Gómez. Madrid 1582.

[3] da Casa, F. F., Echeverría, E., Celis,F., 2007. The intervention under soil level, the importance of its knowledge. The technique of the reinforced grouting. Informes de la Construcción. Ed Instituto Torroja CSIC, Madrid. Spain 
[4] da Casa, F., Echeverría, E., Celis,F., 2002 Las particularidades específicas del recalce de cimentaciones en el patrimonio arquitectónico." Libro de actas del I Congreso del GEIIC. Conservación del Patrimonio. Ed. Grupo Español del International Institute for Conservation of Historic and Artistic Works.

[5] da Casa, F., Echeverría, E., Celis,F.,Chias,P 2006. "Las técnicas de intervención bajo rasante, la importancia de su conocimiento y difusión en la Arquitectura." II Jornadas de Investigación de Arquitectura y Urbanismo IAU06. Ed UPC. Barcelona

[6] Andrea Palladio, Los Cuatro Libros de Arquitectura 1524

[7] Cristóbal de Rojas, Teoría y práctica de Fortificación 1598

[8] Fray Laurencio San Nicolás, Arte y Uso de Arquitectura 1639

[9] Genaro Brizguz y Bru, Escuela de Arquitectura Civil 1738

[10] Cristiano Rieger, Elementos de Toda la Arquitectura 1763

[11] Manuel Fornes y Gurrea, Práctica del Arte de Edificar 1841

[12] P. Celestino Espinosa, Construcciones de Albañilería 1859

[13] Ricardo Marcos y Bausá, Manual del Albañil 1879

[14] Florencio Ger y Lobez, Construcción Civil, 1898

[15] Ëtienne Barberot, Tratado práctico de edificación 1927 